ISSN 1678-3921

Journal homepage: www.embrapa.br/pab

For manuscript submission and journal contents, access: www.scielo.br/pab

\section{Intestinal integrity and performance of turkeys subjected to inoculation of Salmonella Enteritidis and a diet supplemented with lactulose}

\begin{abstract}
The objective of this work was to evaluate the effects of lactulose $\left(0.03 \mathrm{~mL} \mathrm{~kg}^{-1}\right)$ on the intestinal health and weight gain of turkeys subjected to the inoculation of Salmonella serovar (sv.) Enteritidis (SE). A total of 280 turkeys, with one day of age, were distributed in the following treatments: T1, negative control; T2, group that received only lactulose; T3, group subjected to the inoculation of approximately $7.0 \times 10^{5} \mathrm{CFU} \mathrm{mL} \mathrm{mL}^{-1} \mathrm{SE}$; and $\mathrm{T} 4$, group subjected to the inoculation of approximately $7.0 \times 10^{5} \mathrm{CFU} \mathrm{mL}^{-1} \mathrm{SE}$ and treated with lactulose. Poultry performance was evaluated weekly, and seven turkeys from each treatment were euthanized to collect duodenum and jejunum fragments for the histomorphometric analysis. A lower weight gain was observed in the group that received only the pathogen, and the best performance was observed in the lactulose-treated group. The histomorphometric analysis showed a higher villus:crypts ratio in the duodenum and jejunum samples of the negative control and of the group of turkeys at 7 and 21 days of age treated with the lactulose-supplemented diet. Lactulose allows of a better intestinal development of turkeys until 42 days of age, but it does not interfere with poultry performance.
\end{abstract}

Index terms: Meleagris gallopavo formadomestica, avian salmonellosis, histomorphometry, prebiotic, weight gain.

\section{Integridade intestinal e desempenho de perus submetidos à inoculação de Salmonella Enteritidis e a uma dieta suplementada com lactulose}

Resumo - O objetivo deste trabalho foi avaliar os efeitos da lactulose $\left(0.03 \mathrm{~mL} \mathrm{~kg}^{-1}\right)$ sobre a saúde intestinal e o ganho de peso de perus submetidos à inoculação de Salmonella sorovar (vs.) Enteritidis (SE). Um total de 280 perus, com um dia de idade, foram distribuídos nos seguintes tratamentos: T1, controle negativo; T2, grupo que recebeu apenas lactulose; T3, grupo submetido à inoculação de aproximadamente $7,0 \times 10^{5} \mathrm{UFC} \mathrm{mL}^{-1}$ de SE; e T4, grupo submetido à inoculação de aproximadamente 7,0x10 $\mathrm{UFC} \mathrm{mL}^{-1}$ de SE e tratado com lactulose. O desempenho das aves foi avaliado semanalmente, e sete perus por tratamento foram submetidos à eutanásia, para a coleta de fragmentos do duodeno e do jejuno para a análise histomorfométrica. Observou-se menor ganho de peso no grupo que recebeu apenas o patógeno, e o melhor desempenho, no grupo tratado com lactulose. A análise histomorfométrica mostrou maior relação vilos: criptas nas amostras de duodeno e jejuno do controle negativo, e dos grupos de perus, aos 7 e aos 
21 dias de idade, tratados com dieta suplementada com lactulose. A lactulose proporciona melhor desenvolvimento intestinal de perus até os 42 dias de vida, mas não interfere no desempenho dessas aves.

Termos para indexação: Meleagris gallopavo formadomestica, salmonelose aviária, histomorfometria, prebiótico, ganho de peso.

\section{Introduction}

Intestinal integrity has a direct impact on the efficiency of animal production, as the gastrointestinal tract is the most exposed organ to a variability of hazardous substances, and it acts as a selective barrier between the epithelial tissues and the intestinal lumen. The bird spends about $20 \%$ of the gross energy consumed to maintain the intestinal epithelium (Franco, 2009). Thus, when lesions occur in this tissue, in addition to reducing the volume of digested and absorbed substrate, there is even a greater energy demand for cell renewal, resulting in lower weight gain and better feed conversion. It should also be considered that the gut-associated lymphoid tissue (GALT) acts as a barrier against pathogenic bacteria, therefore, disorders in this tissue may alter the intestinal permeability by modifying the digestion and absorption, making it susceptible to infections (Yegani \& Korver, 2008).

Potentially pathogenic Salmonella enterica include the serovars Typhimurium and Enteritidis, which are important in public health and are difficult to control due to their complex epidemiology involving fecal excretion, environmental contamination, and the existence of many sources of infection (Lima et al., 2016). In early 2006, the European Union decided to restrict the use of antimicrobial growth promoters (AGPs) in the animal production. Because of that restriction, investigations have been conducted with food additives that have the ability to promote intestinal microbiota modulation, as a strategy for controlling enteropathogens, such as Salmonella and, consequently, improve the bird performance.

Lactulose, a disaccharide composed of fructose and lactose, is a product with prebiotic action that influences the colonization by Salmonella, potentiating the growth of beneficial bacteria in the host and, by competition, preventing the pathogen from adhering to mucous membranes, as reported by Sharma \&
Kanwar (2018) in broilers subjected to the inoculation of Salmonella enterica serovar Typhimurium.

In vitro experiments have also shown the inhibitory potential of lactulose against Salmonella enterica serovar Typhimurium. The prebiotic action of lactulose has been observed in swine, and its use has been proposed as a food additive (1\%) to prevent Salmonella in food for humans (Brito et al., 2014).

Another effect of dietary supplementation with prebiotics is the intestinal development, as they increase the villus height in different intestinal segments in the first weeks of life, increasing the weight gain, and improving the feed conversion ratio (Lemos et al., 2016).

In view of limited studies on the application of prebiotics in turkeys, the objective of this work was to evaluate the influence of lactulose on the intestinal health and performance of turkeys subjected to the inoculation of $S$. enterica subsp. enterica serovar Enteritidis.

\section{Materials and Methods}

The experiment was carried out at the Experimental Center for Poultry Diseases and at the Histology Laboratory of the Escola de Veterinária e Zootecnia of the Universidade Federal de Goiás (UFG). The experimental protocols used in the present study were approved by the Research Ethics Committee, under No. 103/09 of the UFG, and they are in accordance with the ethical principles for animal experimentation, adopted by the Sociedade Brasileira de Ciência de Animais em Laboratórios (SBCAL).

A total of 280 turkeys (Meleagris gallopavo formadomestica) of the British United Turkeys of America (Buta) from a commercial hatchery were used. The turkeys were divided into four treatments, with 70 birds each. The treatments were as follows: T1, turkeys received neither microbial inoculum nor lactulose (negative control); T2, turkeys fed a diet supplemented with lactulose at $0.03 \mathrm{~mL} \mathrm{~kg}^{-1}$ body weight (Viana, 2014), from the first to the $21^{\text {st }}$ day of housing (lactulose control); T3, turkeys were subjected to the inoculation of $S$. enterica subsp. enterica serovar Entiritidis (SE) directly in the swallow, in the first day of age, with $1.0 \mathrm{~mL} 0.85 \%$ buffered saline containing

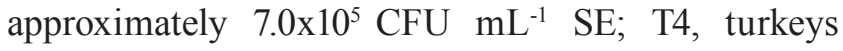
received the inoculum directly in the crop, in the 
first day of age, with $1.0 \mathrm{~mL} 0.85 \%$ buffered saline, containing approximately $7.0 \times 10^{5} \mathrm{CFU} \mathrm{mL}^{-1} \mathrm{SE}$, and lactulose at $0.03 \mathrm{~mL} \mathrm{~kg}^{-1}$ body weight, supplied in the feed, from the first to the $21^{\text {st }}$ day of age (Viana, 2014).

The inoculum was prepared with $S$. enterica serovar Enteritidis isolated from broiler samples, at the concentration of $7 \times 10^{5} \mathrm{CFU} \mathrm{mL}^{-1}$, adjusted by using the MacFarland scale (Fernández et al., 2001).

The diet provided to turkeys was ground corn and soybean meal, formulated according to the food composition and nutritional requirements recommended for the lineage (Buta, 2016), and did not contain animal products, anticoccidial and growth promoting antibiotics. Turkeys of all treatments received the same diet, provided ad libitum throughout the experimental turkey rearing period. Microbiological analyses for checking the presence of Salmonella were performed with the raw materials used in the manufacture of the feed, which showed negative results, according to the requirements by the Ministry of Agriculture, Livestock and Supply (Brasil, 2003).

The weighing of the turkeys the rations prepared for them were performed at 7, 21, 42, and 60 days of age, to calculate feed intake, weight gain, and feed conversion ratio. Dead birds were identified and weighed to adjust feed intake and feed conversion ratio.

At the same ages, 7 turkeys per treatment were subjected to euthanasia, and fragments of duodenum and jejunum were collected, placed in $10 \%$ buffered neutral formalin, and stained with hematoxylin-eosin (HE). From each slide, the scanned images were read in a bright field optical microscope (Carl Zeiss, Jenaval, Germany) in the computer, using the digital video camera and the capture card Image $\mathbf{J}$ software (Rasband, 2004) was used for the morphometric measurements of villus length and crypt depth.

The micrometer quantified histomorphometry was performed, adopting the criteria proposed by Uni et al. (1998). The height of the villus was measured from the villus apex to the base of the villus' junction with the crypt. The crypt depth was defined as the crypt invagination depth with the adjacent villi. The ratio between villus height and crypt depth was also determined. For each slide, the readings were performed for 5 villus heights and 5 crypt depths, totaling readings of 25 villus heights and 25 crypt depths per slide, always from the right to the left of the cut.
Histomorphometry and performance results were subjected to the analysis of variance, and the means were compared, when necessary, by the Tukey's test, at 5\% probability, using the Statistical Analysis System (SAS 9.2) (Sampaio, 2011).

\section{Results and Discussion}

The initial bird weights were very homogeneous, ranging from 63.62 to $64.77 \mathrm{~g}$ per bird (Table 1). At seven days of age, a difference was observed only for feed conversion ratio. The best and the worst feed conversions were observed, respectively, for the negative control and groups subjected to the inoculation of SE. It should be noted that, at birth, birds do not have an established intestinal microbiota, which is established through ingestion or contact with microorganisms in the first days of life (Paixão \& Castro, 2016). The presence of Salmonella, without lactulose in the turkeys, probably caused intestinal changes that reduced the absorption of nutrients, resulting in a worse conversion.

At 60,21 , and 42 days, the mean weight and weight gain were higher for the lactulose control group than for the group inoculated with SE, but no treatment differed from the control. Unlike the present study, Micciche et al. (2018) have found improvement in the performance of birds that received lactose, which is one of the components of lactulose.

At 7 days of age, mean villus height values of duodenum were influenced by the inoculation of SE (Table 2), and turkey duodena inoculated with the bacteria showed the lowest villus height values and greater crypt depths. The lower development of the intestinal mucosa in the first week of age were negatively affected by the use of nutrients in the diet and showed a worse feed conversion (Rodríguez et al., 2015) .

However, the highest villus to crypt ratio was observed in the lactulose control and in the negative control. At 21 days of age, there were lower values of villus heights and greater crypt depths in the group that undergone inoculation of SE; and the highest ratio of villi to crypts was also observed in the duodenum of turkeys that received only lactulose.

Lactulose releases acids in the intestinal mucosa that reduce the $\mathrm{pH}$ and promote the intestinal development, with greater development of villus crypt relationships 
(Névoa et al., 2013). This could have a desirable effect on the animal performance because the growth potential and feed efficiency in turkeys are directly correlated with the intestinal development (Bohórquez et al., 2011).

In the histomorphometric analyses of the jejunum (Table 3), at 7 days of age, there were higher villus heights in the negative control. Lower villus heights occurred in the groups subjected to inoculation of, with, or without lactulose. The highest crypt depths were observed in the SE group.

At 21 days, higher villus heights were also observed for the control and lactulose groups, while the highest crypt depths were found in the SE group, which resulted in higher mean villus to crypt ratios in the negative control and lactulose control groups. Villi reduce their size due to increased cell loss, which results in an increase of crypt cell production and crypt depth (Andrade et al., 2012).

At 42 days of age, there were significant differences only for villi height, with the highest means recorded in the lactulose group; however, this difference was not sufficient to alter crypt depths and villus to crypts relations in none of the treatments. At this age, Salmonella was not able to interfere with the development of the intestinal mucosa, as observed

Table 1. Initial weight (IW), average weight (AW), weight gain (WG), feed intake (FI), and feed conversion (FC) of turkeys (Meleagris gallopavo formadomestica) subjected to the inoculation of Salmonella enterica serovar Enteritidis (SE) fed a diet supplemented with lactulose, in the period of 1, 7,21, 42, and 60 days of age ${ }^{(1)}$.

\begin{tabular}{|c|c|c|c|c|c|}
\hline Treatment & Initial weight $(\mathrm{g})$ & Average weight (g) & Weight gain $(\mathrm{g})$ & Feed intake $(\mathrm{g})$ & Feed conversion \\
\hline & & & 1-7 days of age & & \\
\hline Negative control & 64.77 & 129.96 & 65.19 & 79.98 & $1.17 \mathrm{~b}$ \\
\hline Lactulose & 64.27 & 138.74 & 74.46 & 92.65 & $1.26 \mathrm{ab}$ \\
\hline SE & 64.00 & 133.00 & 68.99 & 88.86 & $1.31 \mathrm{a}$ \\
\hline SE + lactulose & 63.62 & 134.78 & 71.15 & 89.05 & $1.29 \mathrm{ab}$ \\
\hline P-value & 0.1334 & 0.4829 & 0.4796 & 0.1906 & 0.0325 \\
\hline \multirow[t]{2}{*}{ Coefficient of variation $(\%)$} & 0.82 & 4.99 & 10.11 & 7.51 & 3.90 \\
\hline & & & $1-21$ days of age & & \\
\hline Negative control & 64.77 & $604.95 \mathrm{ab}$ & $540.18 \mathrm{ab}$ & 340.91 & 1.37 \\
\hline Lactulose & 64.27 & $635.54 \mathrm{a}$ & $581.04 \mathrm{a}$ & 356.41 & 1.37 \\
\hline SE & 64.00 & $525.15 b$ & $461.14 b$ & 328.50 & 1.45 \\
\hline SE + lactulose & 63.62 & $519.42 \mathrm{~b}$ & $455.80 \mathrm{~b}$ & 323.74 & 1.39 \\
\hline P-value & 0.1334 & $<0.0001$ & $<0.0001$ & 0.2597 & 0.5696 \\
\hline \multirow[t]{2}{*}{ Coefficient of variation (\%) } & 0.82 & 2.60 & 2.95 & 5.89 & 5.27 \\
\hline & & & $1-42$ days of age & & \\
\hline Negative control & 64.77 & $1,860.87 \mathrm{ab}$ & 1,796.13ab & $2,454.13$ & 1.78 \\
\hline Lactulose & 64.27 & $1,923.27 \mathrm{a}$ & $1,859.40 \mathrm{a}$ & $2,416.30$ & 1.77 \\
\hline SE & 64.00 & $1,778.73 b$ & $1,714.13 b$ & $2,440.67$ & 1.82 \\
\hline $\mathrm{SE}+$ lactulose & 63.62 & $1,920.33 \mathrm{a}$ & $1,856.80 \mathrm{a}$ & $2,383.40$ & 1.74 \\
\hline P-value & 0.1334 & 0.0034 & 0.0033 & 0.2386 & 0.1673 \\
\hline \multirow[t]{2}{*}{ Coefficient of variation (\%) } & 0.82 & 1.91 & 1.98 & 1.69 & 2.38 \\
\hline & & & $1-60$ days of age & & \\
\hline Negative control & 64.77 & $2,670.23 \mathrm{ab}$ & $2,605.47 \mathrm{ab}$ & $4,121.27$ & 2.04 \\
\hline Lactulose & 64.27 & $2,824.83 \mathrm{a}$ & $2,761.27 \mathrm{a}$ & $3,924.47$ & 1.97 \\
\hline SE & 64.00 & $2,585.10 \mathrm{~b}$ & $2,520.50 \mathrm{~b}$ & $3,976.97$ & 1.98 \\
\hline $\mathrm{SE}+$ lactulose & 63.62 & $2,717.77 \mathrm{ab}$ & $2,653.13 \mathrm{ab}$ & $4,078.43$ & 2.04 \\
\hline P-value & 0.1334 & 0.0129 & 0.0129 & 0.1774 & 0.1183 \\
\hline Coefficient of variation (\%) & 0.82 & 2.43 & 2.51 & 2.68 & 1.93 \\
\hline
\end{tabular}

(1)Means followed by different letters, in the same column, differ by Tukey's test, at $5 \%$ probability. 
earlier, since this development stabilizes with the growth of the bird.

Prebiotic products may stimulate the intestinal development by acceleration of the mitotic process in the crypt-villus region and, as a consequence, they stimulate the increases of cell number and villus size

Table 2. Villus heights (VH) and crypt depths (CD), and villus: crypt ratio of turkey (Meleagris gallopavo formadomestica) duodena subjected to the inoculation of Salmonella enterica serovar Enteritidis (SE) and treated with lactulose at 7, 21, 42, and 60 days of age ${ }^{(1)}$.

\begin{tabular}{|c|c|c|c|}
\hline Treatment & $\mathrm{VH}(\mu \mathrm{m})$ & $\mathrm{CD}(\mu \mathrm{m})$ & Villus: crypt \\
\hline & \multicolumn{3}{|c|}{7 days of age } \\
\hline Negative control & $624.57 \mathrm{a}$ & $125.81 \mathrm{~b}$ & $4.96 \mathrm{ab}$ \\
\hline Lactulose & $671.80 \mathrm{a}$ & $88.45 \mathrm{c}$ & $7.60 \mathrm{a}$ \\
\hline SE & $477.90 \mathrm{~b}$ & $175.83 \mathrm{a}$ & $2.72 b$ \\
\hline SE + lactulose & $531.76 \mathrm{~b}$ & $141.83 \mathrm{ab}$ & $3.75 b$ \\
\hline P-value & $<0.0001$ & $<0.0001$ & $<0.0001$ \\
\hline CV (\%) & 5.90 & 7.52 & 6.47 \\
\hline \multirow[t]{2}{*}{ SEM } & 13.8810 & 4.0849 & 0.1186 \\
\hline & \multicolumn{3}{|c|}{21 days of age } \\
\hline Negative control & $1153.20 \mathrm{~b}$ & $229.17 b$ & $5.03 \mathrm{~b}$ \\
\hline Lactulose & $1250.00 \mathrm{a}$ & $144.83 \mathrm{c}$ & $8.63 \mathrm{a}$ \\
\hline $\mathrm{SE}$ & $870.79 \mathrm{~d}$ & $277.67 \mathrm{a}$ & $3.14 \mathrm{c}$ \\
\hline SE + lactulose & $950.72 \mathrm{c}$ & $217.96 \mathrm{~b}$ & $4.36 \mathrm{bc}$ \\
\hline P-value & $<0.0001$ & $<0.0001$ & $<0.0001$ \\
\hline CV (\%) & 3.22 & 8.46 & 11.89 \\
\hline \multirow[t]{2}{*}{ SEM } & 13.9038 & 7.5114 & 0.2442 \\
\hline & \multicolumn{3}{|c|}{42 days of age } \\
\hline Negative control & 1831.0 & $287.41 \mathrm{ab}$ & 6.37 \\
\hline Lactulose & 1933.8 & $229.10 \mathrm{c}$ & 8.44 \\
\hline $\mathrm{SE}$ & 1742.3 & $328.55 \mathrm{a}$ & 5.30 \\
\hline $\mathrm{SE}+$ lactulose & 1864.3 & $249.25 b c$ & 7.48 \\
\hline P-value & 0.6079 & $<0.0001$ & 0.1789 \\
\hline CV (\%) & 13.39 & 10.79 & 26.87 \\
\hline \multirow[t]{2}{*}{ SEM } & 100.7296 & 12.0532 & 0.7670 \\
\hline & \multicolumn{3}{|c|}{60 days of age } \\
\hline Negative control & 2189.3 & $329.15 \mathrm{ab}$ & 6.65 \\
\hline Lactulose & 2235.2 & $312.67 \mathrm{~b}$ & 7.15 \\
\hline $\mathrm{SE}$ & 2058.2 & $360.91 \mathrm{a}$ & 5.70 \\
\hline $\mathrm{SE}+$ lactulose & 2126.7 & $324.65 \mathrm{ab}$ & 6.55 \\
\hline P-value & 0.6032 & 0.0489 & 0.8513 \\
\hline CV (\%) & 11.02 & 8.60 & 14.32 \\
\hline SEM & 100.2666 & 11.6524 & 0.3787 \\
\hline
\end{tabular}

${ }^{(1)}$ Means followed by different letters, in the same column, differ by Tukey's test, at $5 \%$ probability. CV, coefficient of variation. SEM, standard error of the mean.
(Sousa et al., 2015); still, according to these authors, changes in intestinal mucosal structures may be a result of stimulation of beneficial gut microbiota, which allows of the development of larger villi, with up to twice as active cell proliferation and increased rate of migration of crypts to villi in 1.7 times.

Table 3. Villus heights (VH) and crypt depths (CD), and villus: jejunum crypt ratio of turkeys (Meleagris gallopavo formadomestica) subjected to the inoculation of Salmonella enterica serovar Enteritidis (SE) and treated with lactulose at 7, 21, 42, and 60 days of age ${ }^{(1)}$.

\begin{tabular}{|c|c|c|c|}
\hline Treatment & $\mathrm{VH}(\mu \mathrm{m})$ & $\mathrm{CD}(\mu \mathrm{m})$ & Villus: crypt \\
\hline & \multicolumn{3}{|c|}{7 days of age } \\
\hline Negative control & $413.06 b$ & 81.66d & $5.06 \mathrm{a}$ \\
\hline Lactulose & $452.89 \mathrm{a}$ & $94.50 \mathrm{c}$ & $4.79 \mathrm{ab}$ \\
\hline $\mathrm{SE}$ & $356.66 \mathrm{~d}$ & $145.00 \mathrm{a}$ & $2.46 \mathrm{~b}$ \\
\hline SE + lactulose & $383.26 \mathrm{c}$ & $115.167 \mathrm{~b}$ & $3.33 b$ \\
\hline P-value & $<0.0001$ & $<0.0001$ & $<0.0001$ \\
\hline CV (\%) & 3.03 & 3.93 & 4.82 \\
\hline \multirow[t]{2}{*}{ SEM } & 4.9607 & 1.7503 & 0.0745 \\
\hline & \multicolumn{3}{|c|}{21 days of age } \\
\hline Negative control & $663.77 \mathrm{a}$ & $221.00 \mathrm{c}$ & $3.00 \mathrm{a}$ \\
\hline Lactulose & $693.55 \mathrm{a}$ & $197.83 d$ & $3.51 \mathrm{a}$ \\
\hline SE & $549.65 b$ & $289.00 \mathrm{a}$ & $1.90 \mathrm{~b}$ \\
\hline $\mathrm{SE}+$ lactulose & $565.09 \mathrm{~b}$ & $259.83 \mathrm{~b}$ & $2.17 \mathrm{~b}$ \\
\hline P-value & $<0.0001$ & $<0.0001$ & 0.0268 \\
\hline CV (\%) & 5.21 & 2.41 & 7.78 \\
\hline \multirow[t]{2}{*}{ SEM } & 13.1482 & 2.3763 & 0.0818 \\
\hline & \multicolumn{3}{|c|}{42 days of age } \\
\hline Negative control & $916.76 b$ & 335.48 & 2.73 \\
\hline Lactulose & $1,046.93 \mathrm{a}$ & 303.15 & 3.45 \\
\hline $\mathrm{SE}$ & $900.62 \mathrm{~b}$ & 354.09 & 2.54 \\
\hline $\mathrm{SE}+$ lactulose & $922.29 b$ & 326.34 & 2.83 \\
\hline P-value & $<0.0001$ & 0.4372 & 0.6390 \\
\hline CV (\%) & 4.60 & 16.17 & 29.28 \\
\hline \multirow[t]{2}{*}{ SEM } & 17.7872 & 21.7661 & 0.3575 \\
\hline & \multicolumn{3}{|c|}{60 days of age } \\
\hline Negative control & $1,366.15$ & 428.98 & 3.18 \\
\hline Lactulose & $1,408.66$ & 427.50 & 3.30 \\
\hline $\mathrm{SE}$ & $1,295.98$ & 441.13 & 2.94 \\
\hline $\mathrm{SE}+$ lactulose & $1,373.50$ & 432.24 & 3.18 \\
\hline P-value & 0.6349 & 0.9718 & 0.8471 \\
\hline CV (\%) & 11.15 & 12.49 & 22.22 \\
\hline SEM & 61.9668 & 22.0509 & 0.2910 \\
\hline
\end{tabular}

(1) Means followed by different letters, in the same column, differ by Tukey's test, at $5 \%$ probability. CV, coefficient of variation. SEM, standard error of the mean. 
At 60 days of age, there was no effect for villus heights and crypt depths, which reflects the relationship between them, showing that the treatments did not interfere with intestinal development at this age. The intestine of turkeys completes its development during the first 20 to 30 days of age; during this time, it undergoes a period of maturation that involves physiological and morphological adaptations and, after that period, the intestine does not change anymore, except for the physiological process of cell renewal, which occurs every two to five days (Sousa et al., 2015).

\section{Conclusions}

1. Lactulose as a supplement in the diet for turkeys (Meleagris gallopavo formadomestica) allows of a better intestinal development from 7 days until 42 days of age and shows no effect by 60 days of the bird age.

2. Lactulose does not interfere with the performance of turkeys until 60 days of age.

\section{Acknowledgments}

To Coordenação de Aperfeiçoamento de Pessoal de Nível Superior (Capes), for scholarship granted (finance code 001).

\section{References}

ANDRADE, C.Y.T. de; ANDRADE, M.A.; CAFÉ, M.B.; STRINGHINI, J.H.; MORI, A.; MORAES, D.M.C.; ALCÂNTARA, J.B.; COSTA, H.X. Efeitos da Salmonella Enteritidis experimentalmente inoculada na saúde gastrintestinal de perus. Revista Brasileira de Zootecnia, v.41, p.618-623, 2012. DOI: https://doi.org/10.1590/S1516-35982012000300021.

BOHÓRQUEZ, D.V.; BOHÓRQUEZ, N.E.; FERKET, P.R. Ultrastructural development of the small intestinal mucosa in the embryo and turkey poult: a light and electron microscopy study. Poultry Science, v.90, p.842-855, 2011. DOI: https://doi.org/10.3382/ps.2010-00939.

BRASIL. Ministério da Agricultura, Pecuária e Abastecimento. Instrução Normativa $\mathrm{n}^{\circ} 70$, de 6 de outubro de 2003. [Institui o ProgramadeReduçãodePatógenos-MonitoramentoMicrobiológico e Controle de Salmonella sp. em Carcaças de Frangos e Perus]. Diário Oficial da União, 10 out. 2003. Seção1, p.9-10. Available at: $\quad<$ https://pesquisa.in.gov.br/imprensa/jsp/visualiza/index. jsp?data $=10 / 10 / 2003 \&$ jornal $=1 \&$ pagina $=9 \&$ total Arquivos $=140>$. Accessed on: Dec. 42020.
BRITO, J.M. de; FERREIRA, A.H.C.; SANTANA JUNIOR, H.A. de; ARARIPE, M. de N.B. de A.; LOPES, J.B.; DUARTE, A.R.; CARDOSO, E. de S.; RODRIGUES, V.L. Probióticos, prebióticos e simbióticos na alimentação de não-ruminantes revisão. Revista Eletrônica Nutrime, v.11, p.3070-3084, 2014.

BUTA. British United Turkeys of America. BUT Performance Goals. $5^{\text {th }}$ ed. Inglaterra: British United Turkeys, 2016. 6p.

FERNÁNDEZ, A.; LARA, C.; LOSTE, A.; CALVO, S.; MARCA, M.C. Control of Salmonella enteritidis phage type 4 experimental infection by fosfomycin in newly hatched chicks. Comparative Immunology, Microbiology \& Infections Diseases, v.24, p.207216, 2001. DOI: https://doi.org/10.1016/s0147-9571(00)00028-x.

FRANCO, L.G. Integridade intestinal. Nutrition for Tomorrow, n.1, p.20-25, 2009. São Paulo. Available at: <http://www. nftalliance.com.br/>. Accessed on: July 172018.

LEMOS, M.J. de; CALIXTO, L.F.L.; TORRES-CORDIDO, K.A.A.; REIS, T.L. Uso de aditivo alimentar equilibrador da flora intestinal em aves de corte e de postura. Arquivos do Instituto Biológico, v.83, e0862014, 2016. DOI: https://doi.org/10.1590/1808-1657000862014.

LIMA, A.L.; RODRIGUES, D.P.; ARAÚJO, M.S.; REIS, E.M.F.; FESTIVO, M.L.; RODRIGUES, E.C.P.; LÁZARO, N.S. Sorovares e perfil de suscetibilidade a antimicrobianos em Salmonella spp. isoladas de produtos de origem suína. Arquivo Brasileiro de Medicina Veterinária e Zootecnia, v.68, p.39-47, 2016. DOI: https://doi.org/10.1590/1678-4162-7997.

MICCICHE, A.C.; FOLEY, S.T.; PAVLIDIS, H.O.; MCINTYRE, D.R.; RICKE, S.C. A review of prebiotics against Salmonella in poultry: current and future potential for microbiome research applications. Frontiers in Veterinary Science, v.5, p.1-11, 2018. DOI: https://doi.org/10.3389/fvets.2018.00191.

NÉVOA, M.L.; CARAMORI JR., J.G.; VIEITES, F.M.; NUNES, R.V.; VARGAS JUNIOR, J.G. de; KAMIMURA, R. Antimicrobianos e prebióticos nas dietas de animais não ruminantes. Scientia Agraria Paranaensis, v.12, p.85-95, 2013. DOI: https://doi.org/10.18188/sap.v12i2.6619.

PAIXÃO, L.A. da; CASTRO, F.F. dos S. A colonização da microbiota intestinal e sua influência na saúde do hospedeiro. Universitas: Ciências da Saúde, v.14, p.85-96, 2016. DOI: https://doi.org/10.5102/UCS.V14I1.3629.

RASBAND, W.S. ImageJ. Bethesda: National Institutes of Health, 2004. Available at: $<$ https://rsb.info.nih.gov/ij/>. Accessed on: Mar. 202011.

RODRÍGUEZ, J.M.; MURPHY, K.; STANTON, C.; ROSS, R.P.; KOBER, O.I.; JUGE, N.; AVERSHINA, E.; RUDI, K.; NARBAD, A.; JENMALM, M.C.; MARCHESI, J.R.; COLLADO, M.C. The composition of the gut microbiota throughout life, with an emphasis on early life. Microbial Ecology in Health \& Disease, v.26, art.26050, 2015. DOI: https://doi.org/10.3402/mehd. v26.26050.

SAMPAIO, I.B.M. Estatística aplicada à experimentação animal. Belo Horizonte: Fundação de Ensino e Pesquisa em Medicina Veterinária e Zootecnia, 2011. 221p. 
SHARMA, S.; KANWAR, S.S. Effect of prebiotics on growth behavior of Lactobacillus plantarum and their impact on adherence of strict anaerobic pathogens to intestinal cell lines. Journal of Food Safety, v.38, e12384, 2018. DOI: https://doi.org/10.1111/jfs.12384.

SOUSA, D.C.; OLIVEIRA, N.L.A.; SANTOS, E.T.; GUZZI, A.; DOURADO, L.R.B.; FERREIRA, G.J.B.C. Caracterização morfológica do trato gastrointestinal de frangos de corte da linhagem Cobb $500^{\circledR}$. Pesquisa Veterinária Brasileira, v.35, p.61-68, 2015. Supl.1. DOI: https://doi.org/10.1590/S0100736X2015001300011.
UNI, Z.; GANOT, S.; SKLAN, D. Posthatch development of mucosal function in the broiler small intestine. Poultry Science, v.77, p.75-82, 1998. DOI: https://doi.org/10.1093/ps/77.1.75.

VIANA, F.A.B. Drogas de uso corrente em espécie domésticas e de companhia. In: VIANA, F.A.B. Guia Terapêutico Veterinário. 3.ed. [S.1.]: CEM, 2014. 560p.

YEGANI, M.; KORVER, D.R. Factors affecting intestinal health in poultry. Poultry Science, v.87, p.2052-2063, 2008. DOI: https://doi.org/10.3382/ps.2008-00091. 